zacja konferencji była wzorcowa, należy tu z uznaniem podkreślić starania prof. Lecha Dubela i pracowników UMCS. Materiały mają być opublikowane w „Annales UMCS”. Natomiast zmiany w sposobie finansowania szkolnictwa wyższego wzbudziły niepokój, czy uda się kontynuować tradycje konferencji, które dla rozwoju młodych kadr z pewnością mają ogromne znaczenie. Ten znak zapytania i niepokój o przyszłość towarzyszył ostatnim refleksjom uczestników konferencji.

MARIA ZMIERCZAK (Poznań)

\title{
KONFERENCJA NAUKOWA: „WYBITNI PRAWNICY NA UNIWERSYTECIE WROCLAWSKIM”
}

W roku 2011 obchodzony był jubileusz 200-lecia fakultetu prawniczego na Uniwersytecie we Wrocławiu. Wydział ten powstał w roku 1811, kiedy rozkazem Fryderyka Wilhelma III przeniesiono Uniwersytet Viadrina z Frankfurtu nad Odrą do Wrocławia i połączono z wrocławską Leopoldina, tworząc tym samym uniwersytet państwowy. Z tej okazji w PolanicyZdroju między 27 a 29 października 2011 r. odbyła się - zorganizowana przez Instytut Historii Państwa i Prawa oraz Katedrę Doktryn Politycznych i Prawnych Wydziału Prawa, Administracji i Ekonomii Uniwersytetu Wrocławskiego - konferencja naukowa Wybitni prawnicy na Uniwersytecie Wroclawskim, analizująca dorobek intelektualny prawników związanych z tą uczelnią. Pomysłodawcami konferencji byli prof. Maciej Marszał z Katedry Doktryn Politycznych i Prawnych oraz dr Jacek Przygodzki, reprezentujący Instytut Historii Państwa i Prawa.

Obrady, prowadzone przez kierownika Katedry Doktryn Politycznych i Prawnych prof. Marka Maciejewskiego oraz dyrektora Instytutu Historii Państwa i Prawa prof. Mariana J. Ptaka, podzielone były na dwie wyraźne części. Pierwsza odnosiła się do dokonań prawników związanych z wrocławskim środowiskiem naukowym w okresie prusko-niemieckim, nie ograniczając się bynajmniej do ukazania dorobku środowiska niemieckich uczonych, lecz przybliżając także sylwetki wybitnych później Polaków, którzy zdobywali wykształcenie prawnicze we Wrocławiu. Uwaga referentów skupiła się zatem na postaciach Johanna Friedricha Meistera (prof. Marian J. Ptak), Wojciecha Korfantego (prof. Maciej Marszał), Ernsta Ludwiga von Belinga (prof. Józef Koredczuk), Wojciecha Trąmpczyńskiego (mgr Paweł Fiktus), Güntera Schmöldersa (prof. Tomasz Kruszewski), a także Hansa Helfritza (dr Jacek Przygodzki). Z kolei dr Tomasz Dolata przedstawił syntetycznie kariery wrocławskich profesorów prawa w latach 1811-1900. Druga część obrad natomiast koncentrowała się na wybitnych i zasłużonych na różnych polach aktywności prawnikach, mających związki z Uniwersytetem Wrocławskim w okresie powojennym. Rozpoczęła ją prezentacja osiagnięć znakomitego karnisty i rektora Uniwersytetu w latach 1959-1962, prof. Witolda Świdy (dr Andrzej Pasek), zakończyło zaś omówienie twórczości naukowej jego córki - znawczyni procedury karnej - prof. Zofii Świdy, zmarłej nagle w lutym $2011 \mathrm{r}$. (dr Paweł Wiązek). Pozostałe referaty poświęcone zostały prof. Karolowi Joncy (dr hab. Mirosław Sadowski), prof. Janowi Baszkiewiczowi (prof. Marek Maciejewski), prof. Kazimierzowi Orzechowskiemu (prof. Piotr Jurek), prof. Andrzejowi Stelmachowskiemu (mgr Piotr Szymaniec i mgr Paweł Fiktus) oraz Aleksandrowi Małachowskiemu (mgr Marta Mackiewicz). 
W bardzo interesującej i intensywnej części dyskusyjnej podjęto przede wszystkim trudny temat udziału uniwersyteckich prawników w tworzeniu ideologii i działalności aparatu władzy państwa totalitarnego, w tym zwłaszcza zaangażowania niemieckich uczonych - jak chociażby Hansa Helfritza - w doktrynę i praktykę nazizmu. Wspominano także osiagnięcia innych znakomitych prawników, którym nie poświęcono całych wystapień, a więc między innymi Theodora Mommsena, Karla Augusta Unterholznera, Kamila Stefki, Tadeusza Bigo, Andrzeja Mycielskiego, Seweryna Wysłoucha, Franciszka Longchamps de Berier, Franciszka Ryszki, Waleriana Pańki i Jana Kosika. Wszystkie omawiane podczas dyskusji kwestie znajdą się zapewne, wraz z tekstami referatów, w publikacji, która już niebawem będzie efektem konferencji.

PIOTR SZYMANIEC (Wroclaw)

\section{MIĘDZYNARODOWA KONFERENCJA NAUKOWA DLA UCZCZENIA JUBILEUSZU ABGB W PRADZE}

W dniach 22-23 listopada 2011 r. na Wydziale Prawa Uniwersytetu Karola w Pradze odbyła się międzynarodowa konferencja naukowa z okazji 200-lecia austriackiego kodeksu cywilnego ABGB. Obrady, uroczyście otwarte z udziałem władz Wydziału Prawa Uniwersytetu Karola oraz zaproszonych gości, między innymi władz korporacji prawniczych, prowadzone były równolegle w dwóch sekcjach: historycznoprawnej oraz cywilistycznej.

Obradom sekcji historycznoprawnej przewodniczyl wybitny czeski historyk prawa, prof. Karel Maly, wieloletni prorektor i rektor Uniwersytetu Karola w Pradze. Wśród zagranicznych gości, którzy wzięli udział w tej części konferencji znaleźli się między innymi prof. Werner Ogris z Uniwersytetu Wiedeńskiego, prof. Monika Niedermayr z Innsbrucku, prof. Gerhard Lingelbach z Friedrich-Schiller Uniwersität, a także pisząca te słowa prof. Dorota Malec z Uniwersytetu Jagiellońskiego. Wśród referentów najliczniej reprezentowani byli uczeni z ośrodka praskiego, ale także Bratysławy, Brna i Olomuńca.

Program zaledwie dwudniowej konferencji obejmował 29 referatów, poświęconych wybranym zagadnieniom dziejów prawa cywilnego, spośród których na pierwszym planie znalazły się problemy wpływu ABGB na prace kodyfikacyjne w okresie międzywojennym i pierwszych latach po II wojnie światowej, podejmowane w szerokim, nie tylko śrokowoeuropejskim zakresie.

Konferencję otworzył interesujący, oparty na bogatych archiwalnych podstawach źródłowych referat prof. Moniki Niedermayr z Innsbrucku, poświęcony orzecznictwu Sądu Najwyższego i praktyce sądowej z okresu wprowadzania ABGB w życie. Prof. Gerhard Lingelbach z Jeny skoncentrował swe wystapienie wokół problematyki wpływu ABGB na saksoński kodeks cywilny z roku 1863/1865, i pośrednio, poprzez ów kodeks, na niemiecką kodyfikację BGB. W syntetycznym referacie prof. Radima Seltenreicha przedstawione zostały starania kodyfikacyjne na terytoriach niemieckich w XVIII i XIX w.

Kolejni referenci skoncentrowali swe wystapienia na problematyce XX-wiecznej, począwszy od prac nad nowelizacją ABGB w latach I wojny światowej, z interesującym wątkiem polskim - udziałem w nich krakowskiego cywilisty, a zarazem galicyjskiego polityka Stanisława Madeyskiego (Ladislav Soukup). Ogólne zagadnienia kodyfikacji prawa i wpływu między innymi $\mathrm{ABGB}$ na działania kodyfikacyjne w krajach europejskich w okresie międzywojennym zaakcentowane zostały w referatach Jana Kuklika, Petry Skṙejpkovej oraz Doroty Malec. Podjęto także wątek ustawodawstwa w zakresie prawa cywilnego dla terenów słowackich w latach 1938-1945 (Ondřej Podolec), relacji między przepisami ABGB a Konstytucją Czechosłowacji 